\title{
Online Appendix to: The Dynamic Effects of Personal and Corporate Income Tax Changes in the United States
}

\author{
Karel Mertens and Morten O. Ravn*
}

\section{Contents}

1 Robustness of Benchmark SVAR 1

1 .1 Deterministic Trends and First Differences . . . . . . . . . . . . . . . . 1

1.2 Including Fiscal Foresight Variables . . . . . . . . . . . . . . . . 2

1.3 Alternative Proxies Generated from Regressions . . . . . . . . . . . . . . . . . 3

1.4 Timing Error in the Narrative Shocks . . . . . . . . . . . . . . . . 4

2 Private vs. Public Sector Employment Responses $\quad 5$

3 Robustness of VAR with Monetary Variables $\quad 6$

3.1 Alternative Measures of Inflation . . . . . . . . . . . . . . . . . 6

3 .2 Benchmark VAR System Augmented with Monetary Variables . . . . . . . . . . 8

4 Data for the Narrative Tax Changes $\quad 11$

*Mertens: Department of Economics, Cornell University, km426@cornell.edu; Ravn: Department of Economics, University College London, m.ravn@ucl.ac.uk. 


\section{Robustness of Benchmark SVAR}

\subsection{Deterministic Trends and First Differences}

Figure A-1 presents two alternative time series specifications. In the first row, results are shown when a linear-quadratic time trend is added to the benchmark specification. The second row of figure A-1 depicts the output effects when all the variables are included in first differences. Including a deterministic time trend yields slightly larger output effects in the first few quarters compared to our benchmark, and a gradual return to trend in the long run. First-differencing yields a larger output response to an APITR cut at all horizons, a slightly lower response to an ACITR cut and in both cases the expansionary effects of tax cuts are permanent. We obtain very similar results if we leave the tax rates in levels.

(A) Personal Income Tax Cut
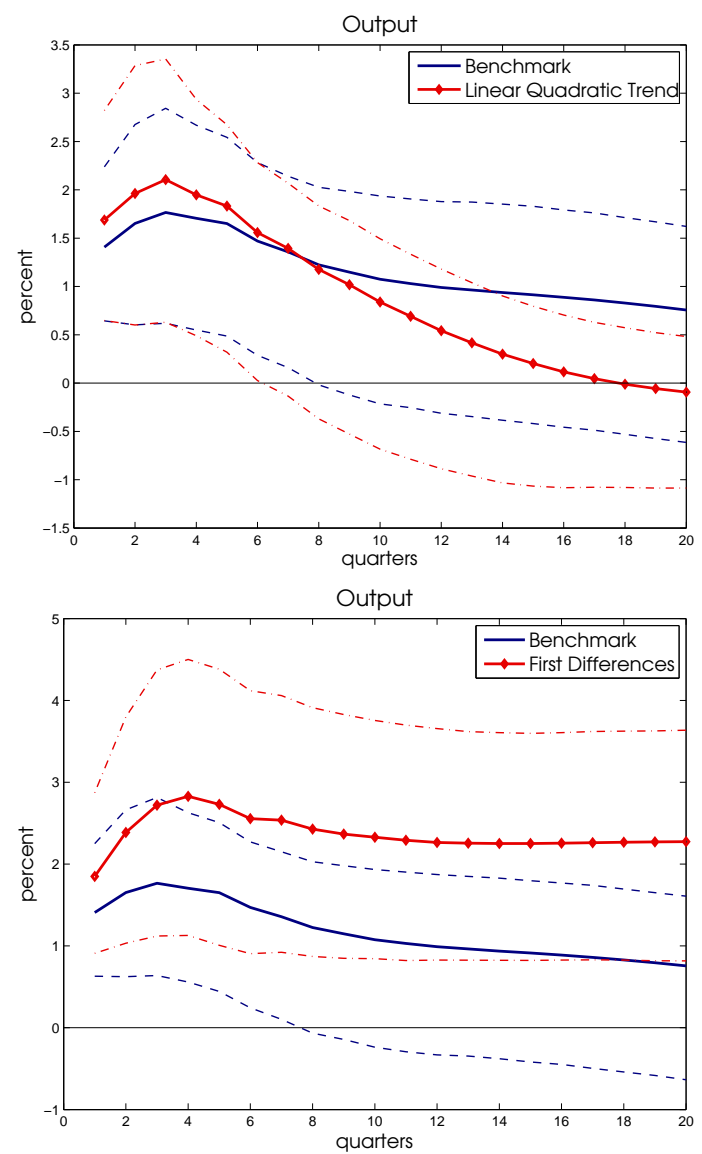

(B) Corporate Income Tax Cut
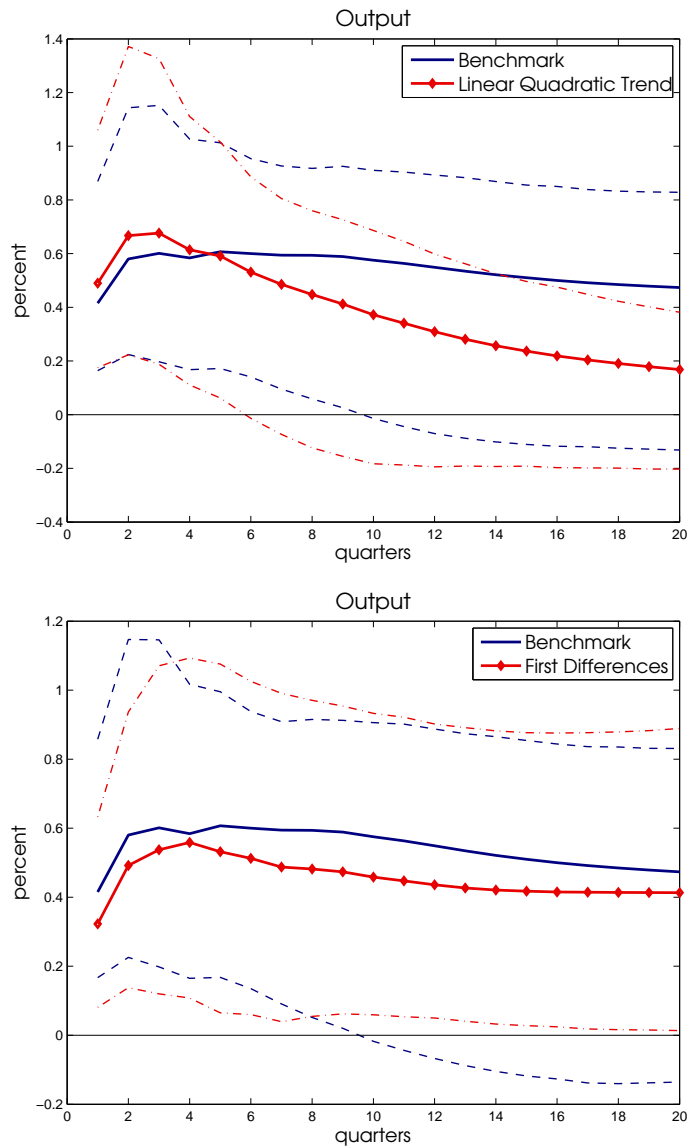

Figure A-1 Alternative Trend Assumptions: Response to One Percentage Point Cut In Average Tax Rates. Broken lines are 95\% percentile intervals. 


\subsection{Including Fiscal Foresight Variables}

Figure A-2 contains the estimated output responses that result from extending the set observables of the benchmark specification with additional variables that contain information about future changes in fiscal policy. Each of the following series were rotated in sequentially as the 8th variable: implicit measures of expected future taxes derived from the municipal bond prices obtained from Leeper, Walker and Yang (2011), based on spreads for bonds with maturity of either one or five years; the accumulated excess returns of large US military contractors constructed by Fisher and Peters (2010); and Ramey's (2011) defense spending news variable based on professional forecasters' projections of the path of future military spending. The implicit tax rate measures of Leeper, Walker and Yang (2011) are only available from 1953Q2 onwards and therefore the sample was shortened accordingly.

(A) Personal Income Tax Cut

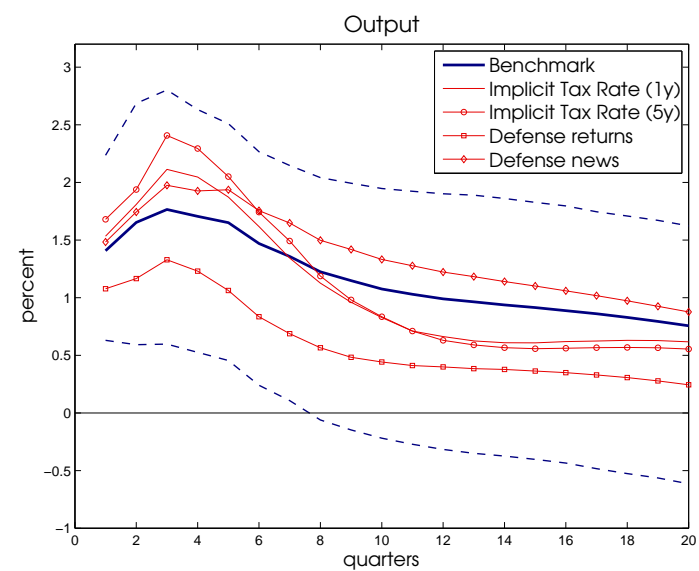

(B) Corporate Income Tax Cut

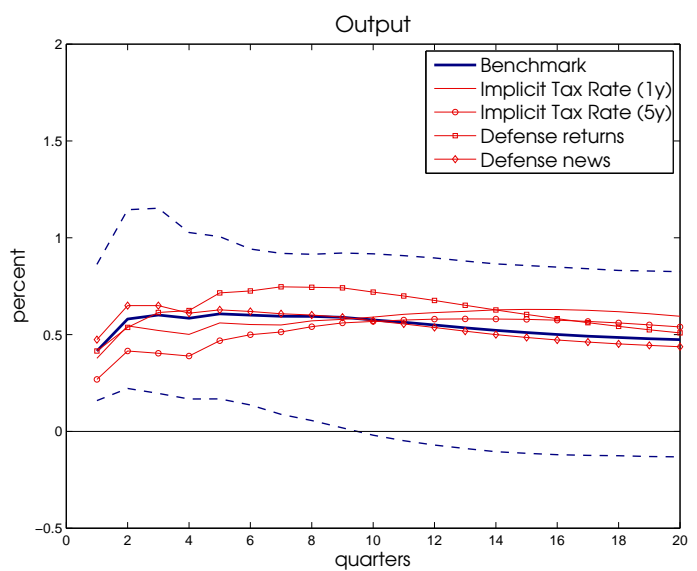

Figure A-2 Including Fiscal Foresight Variables: Response to One Percentage Point Cut In Average Tax Rate. Broken lines are $95 \%$ percentile intervals of the benchmark specification.

The additions yield output responses that are all similar to the benchmark specification. The largest changes occur for the response to a cut in the personal income tax when including Ramey's (2011) defense news variable, and for the response to a cut in the corporate income tax when including the 5 year municipal bond spread. In both these cases the short run output responses are somewhat lower than in our benchmark specification, although they remain well within the $95 \%$ percentile intervals. 


\subsection{Alternative Proxies Generated from Regressions}

Figure A-3 contains the estimated output responses when we replace the proxy used in the benchmark specification with three alternative proxy variables for tax shocks. The latter where obtained by first regressing the subset of nonzero observations of the narrative shocks on, respectively: two lags of the implicit expected future tax rate measure of Leeper, Walker and Yang (2011) derived from bonds with maturity of one year; one lag of each of the implicit expected future tax rate measures for one and five year bonds; and one lag of the debt-to-GDP ratio. The proxies are then constructed from the residuals in these regressions. The small number of observations do not permit more than one or two regressors. Because of the high persistence of the debt-to-GDP ratio we include only one lag to avoid multicollinearity problems. Tests on the slope coefficients based on standard bootstrapping techniques do not indicate statistical significance. Figure A-3 shows that the point estimates remain fairly close to our original benchmark specification.

(A) Personal Income Tax Cut

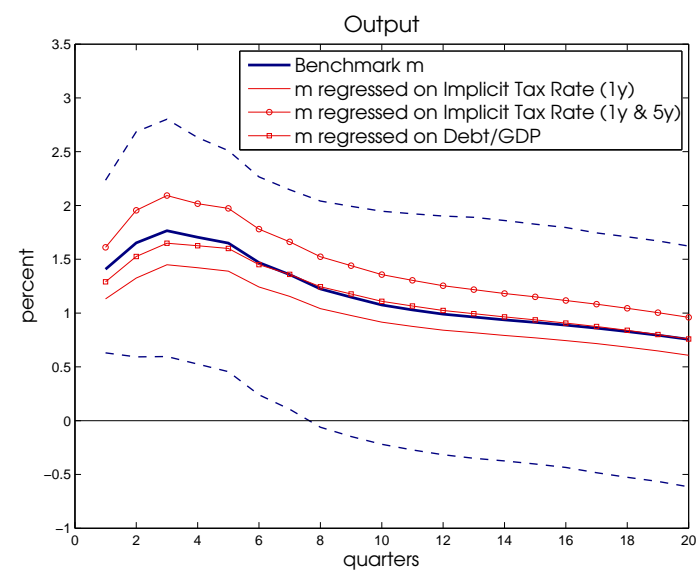

(B) Corporate Income Tax Cut

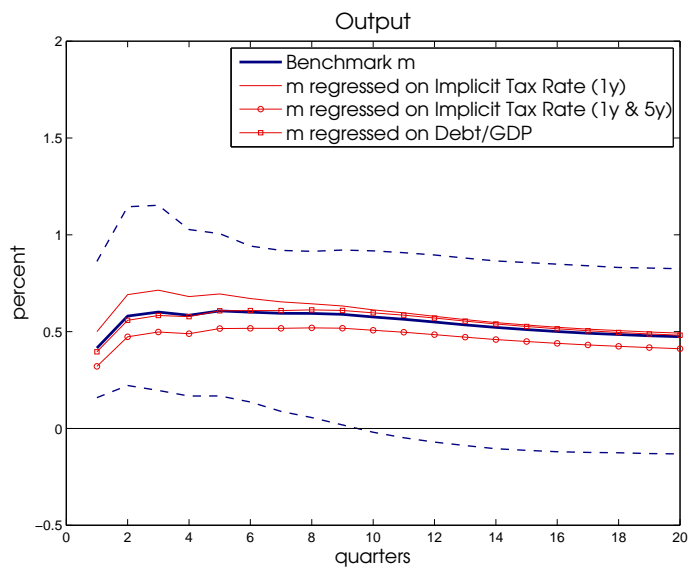

Figure A-3 Alternative Proxies Generated from Regressions: Response to $1 \%$ Cut In Average Tax Rate. Broken lines are $95 \%$ percentile intervals of the benchmark specification. 


\subsection{Timing Error in the Narrative Shocks}

To evaluate the role of error in the timing of the narrative measures of tax changes, we perform simulation experiments similar to Ramey (2011). We simulate for $i=P I, C I$

$$
\tilde{m}_{t}^{i}=\left(1-\mu_{t}^{i}\right) m_{t}^{i}+\rho_{t}^{i} \mu_{t}^{i} m_{t-1}^{i}+\left(1-\rho_{t}^{i}\right) \mu_{t}^{i} m_{t+1}^{i}, \mu_{t}^{i} \sim U(0,0.50), \rho_{t}^{i} \sim B(0.5)
$$

and re-estimate the impulse responses using $\tilde{m}_{t}^{i}$ for identification. Proxies simulated from (1) assign with probability 0.5 up to $50 \%$ of the measurement one quarter too early or too late. Figure A-4 shows the mean as well as $95 \%$ percentiles of the distribution of output responses generated from 10,000 samples and compares it to the point estimates of the benchmark. The figure shows that adding the timing noise, not surprisingly, leads to variation in the estimates. For the CI response the simulated responses are centered around the original point estimates and not too dispersed. For the PI response, the simulated responses are centered somewhat below the original impulse responses. Note that the original estimates are already robust to this type of timing error, so the presence of timing error does not affect our conclusions.

(A) Personal Income Tax Cut

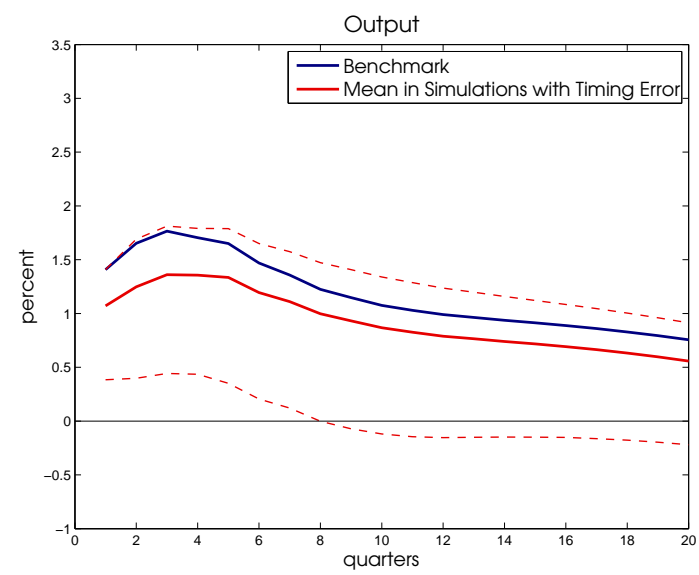

(B) Corporate Income Tax Cut

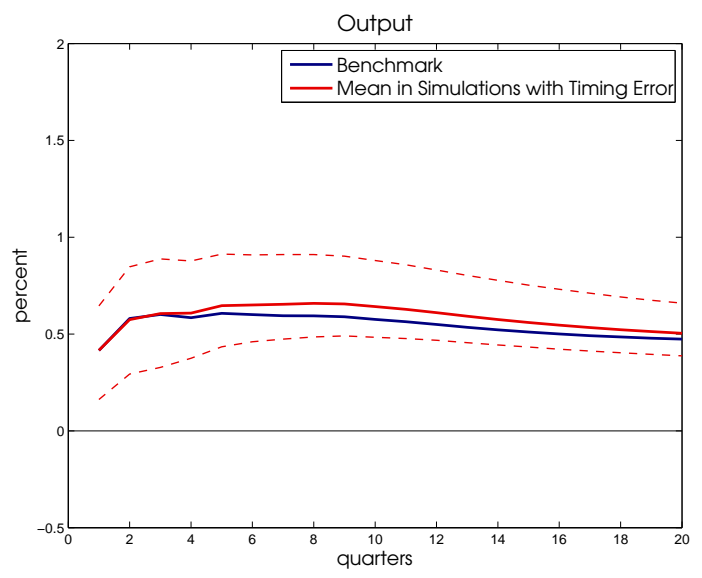

Figure A-4 Adding Timing Noise : Response to One Percentage Point Cut In Average Tax Rates. Broken lines are $95 \%$ percentile intervals of the simulated responses. 


\section{Private vs. Public Sector Employment Responses}

To verify whether there is a difference between the employment response to tax cuts in the public and private sector, we replace total economy employment in the VAR specification with the labor market variables with the private sector and total government employment series from Francis and Ramey (2009). Figure A-5 shows that private sector employment responds significantly to a cut in the personal income tax in the short run, whereas the response to the corporate tax cut is smaller and never significant. Interestingly, we find that public sector employment decreases after cuts in both types of taxes.

(A) Personal Income Tax Cut
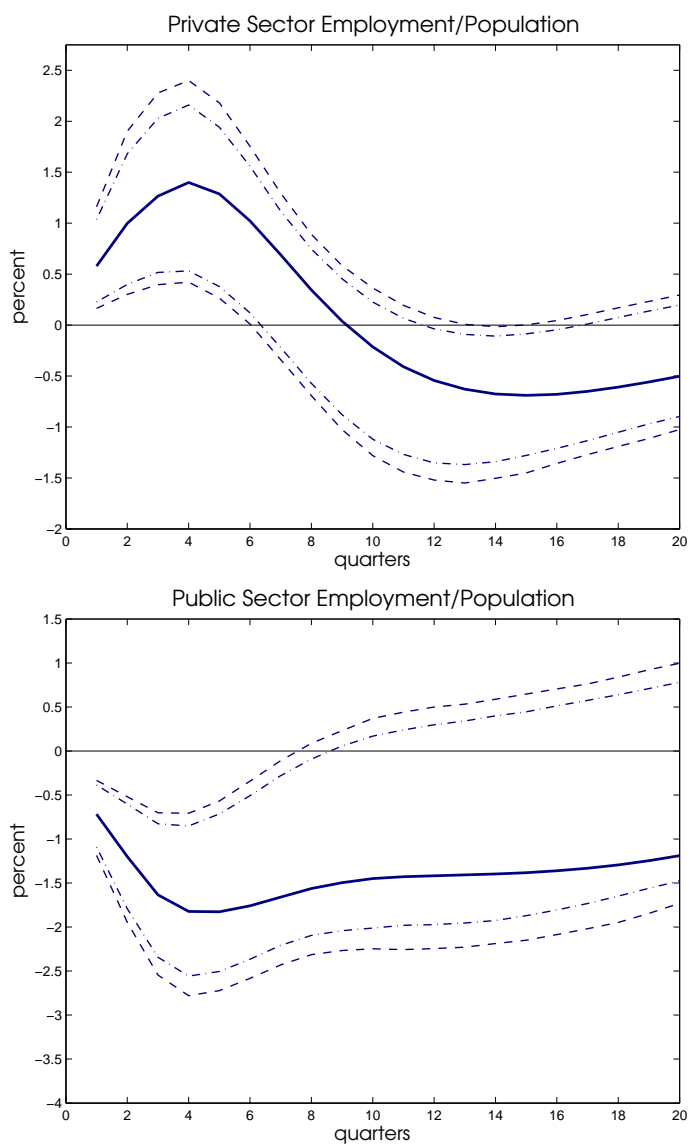

(B) Corporate Income Tax Cut
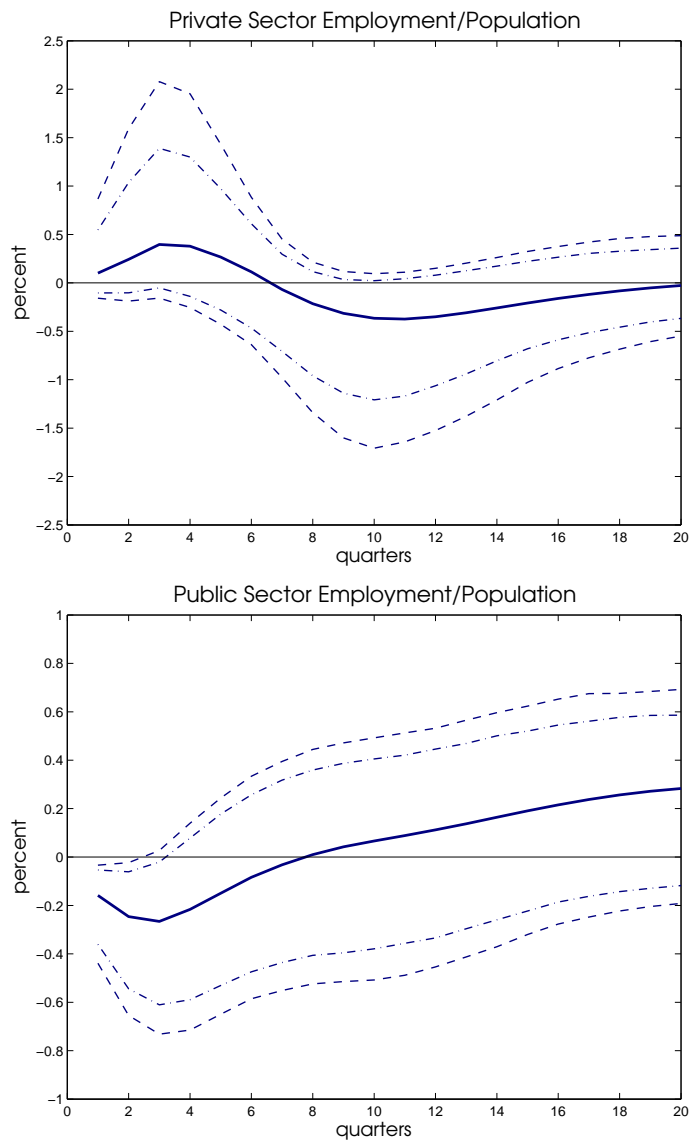

Figure A-5 Private vs. Public Sector Employment: Response to One Percentage Point Cut In Average Tax Rates. Broken lines are $90 \%$ and $95 \%$ percentile intervals. 


\section{Robustness of VAR with Monetary Variables}

\section{3 .1 Alternative Measures of Inflation}

Figure A-6 depicts the response of inflation when using different measures for the price level. These were obtained by replacing the PCE deflator in the VAR specification with monetary variables with, respectively, the Consumer Price Index constructed by the Bureau of Labor Statistics (FRED: CPIAUCSL) and the GDP deflator (NIPA 1.1.9 line 1) from the national accounts. The response of CPI inflation is very similar to the response of PCE inflation reported in the main paper, including a significant decrease in response to a corporate tax cut. The response of the annualized change in the GDP deflator, a broader measure of inflation, is somewhat different. In response to a personal income tax cut, there is a marginally significant (at the $90 \%$ level) decrease in prices that however quickly reverses in subsequent quarters. In response to a corporate tax cut, we still find a persistent decrease inflation but only from the second quarter onwards. 
(A) Personal Income Tax Cut
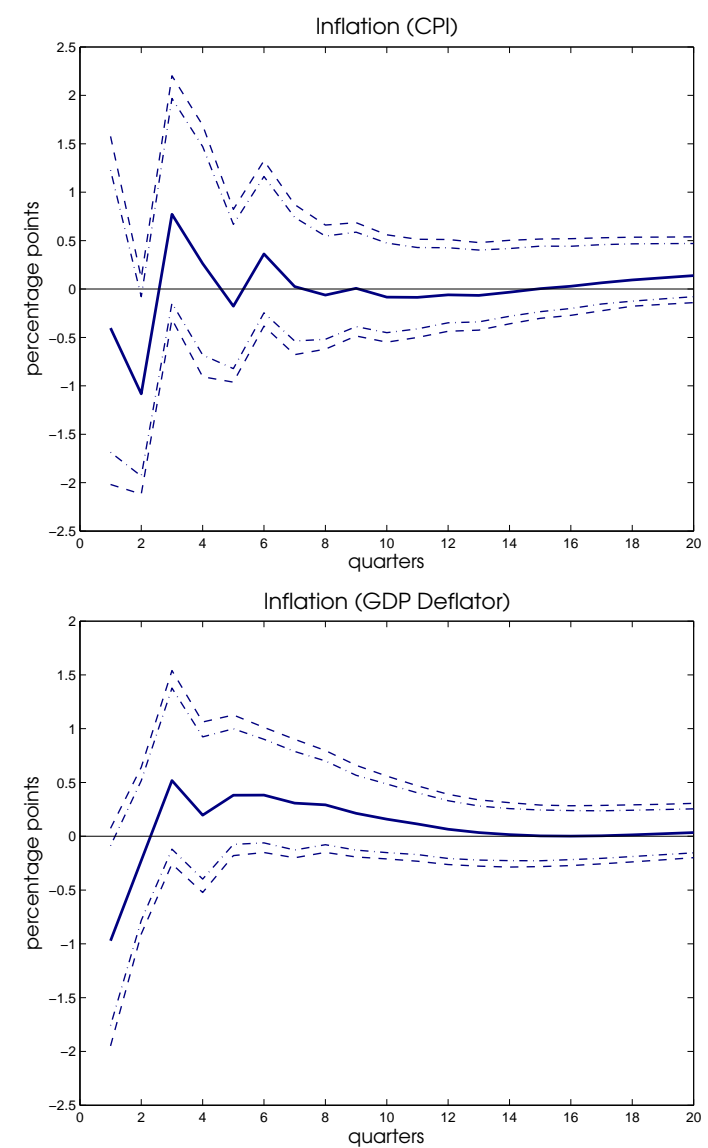

(B) Corporate Income Tax Cut
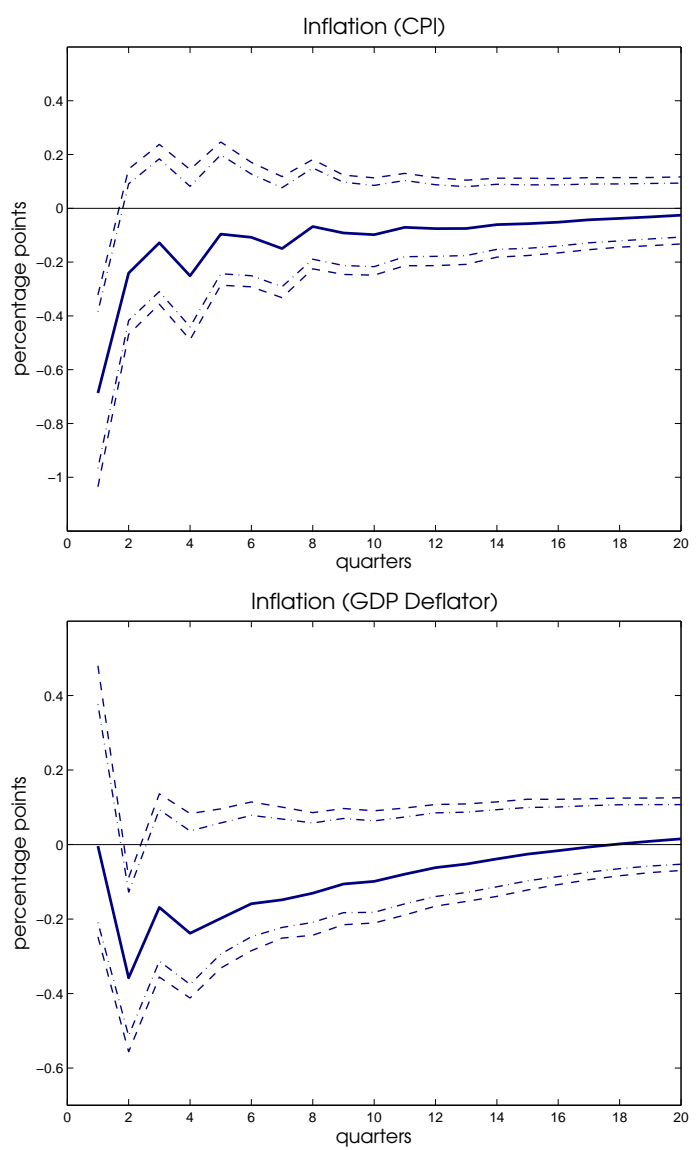

Figure A-6 Alternative Measures of Inflation: Response to One Percentage Point Cut In Average Tax Rates. Broken lines are $90 \%$ and $95 \%$ percentile intervals. 


\section{3 .2 Benchmark VAR System Augmented with Monetary Variables}

Figures A-7 and A-8 report the responses of the key variables to both types of tax shocks in a specification with 10 variables. The variables included are the seven series included in the benchmark specification plus the effective federal funds rate, the (log) level of nonborrowed reserves and the

$(\log )$ level of the price index for personal consumption expenditures. This specification differs from the specification with monetary variables in the paper because both tax bases are included as observables. The responses for this larger specification are quantitatively and qualitatively very similar those reported in the paper, with somewhat larger confidence intervals which is natural given the larger number of parameters to be estimated (the number of lags kept to four). One minor difference is that the short run decline in inflation in response to the corporate tax cut is no longer significant at the $95 \%$ level. 

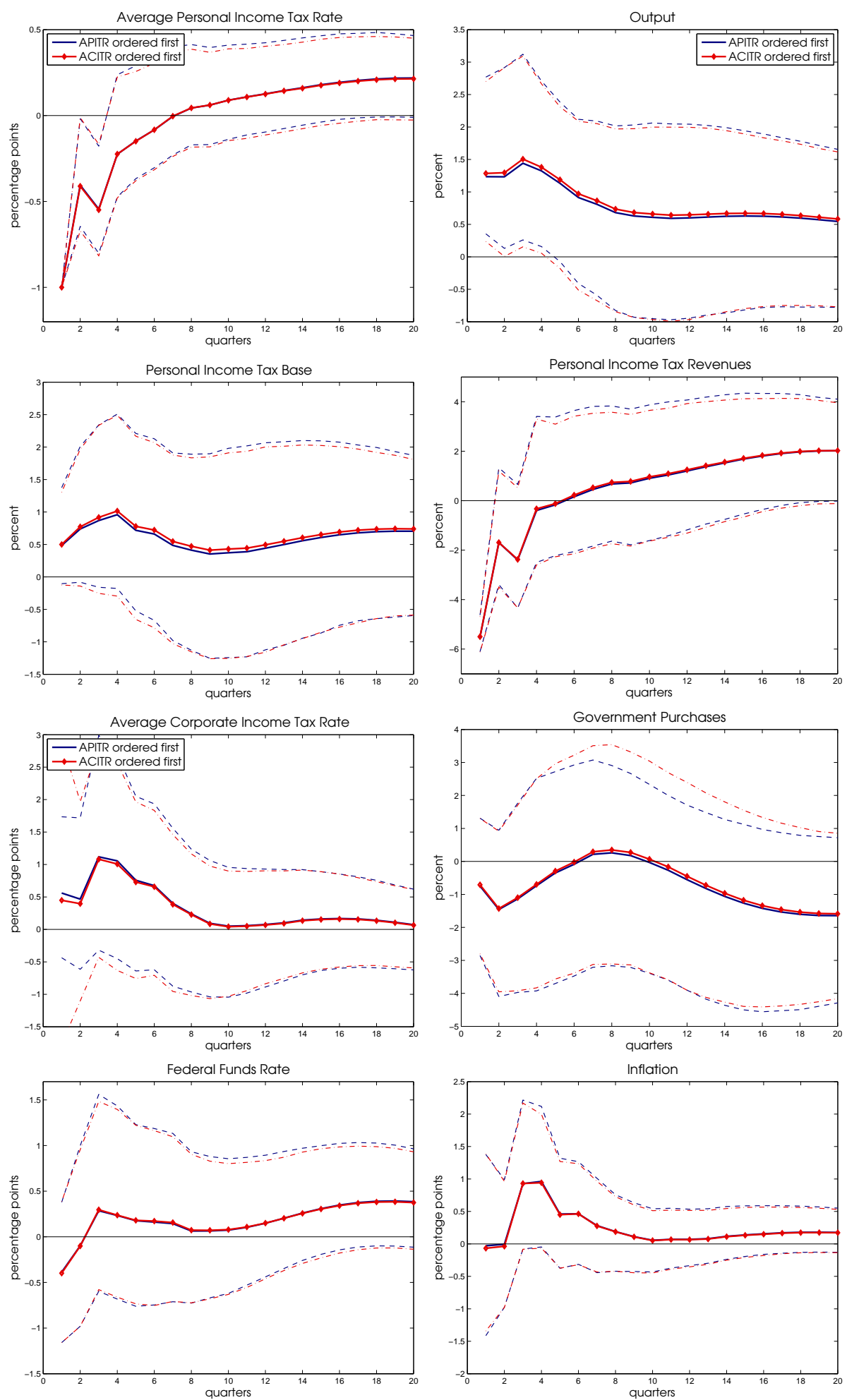

Figure A-7 Larger Monetary VAR: Response to One Percentage Point Cut In Average Personal Income Tax Rate. Broken lines are 95\% percentile intervals. 

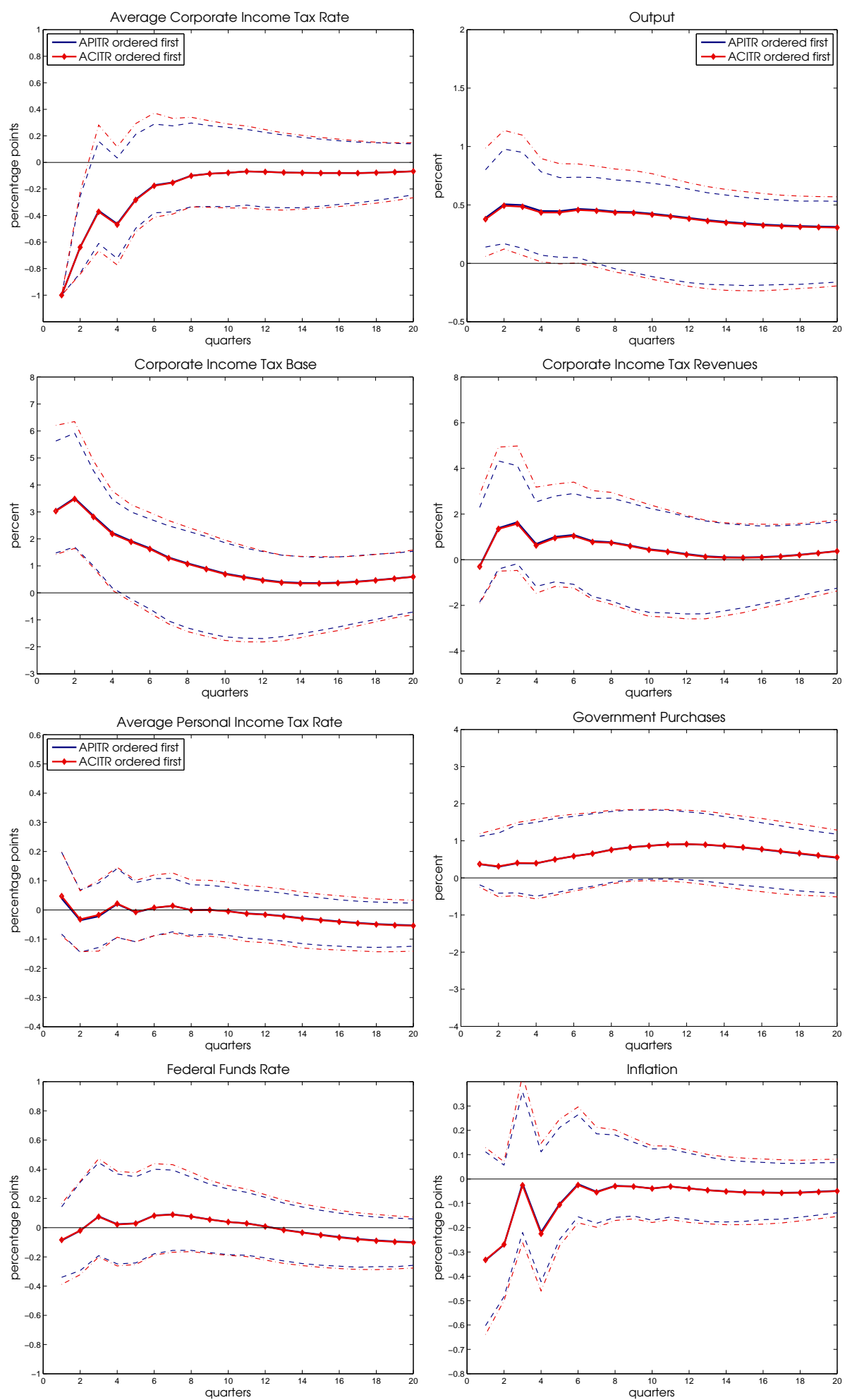

Figure A-8 Larger Monetary VAR: Response to One Percentage Point Cut In Average Corporate Income Tax Rate. Broken lines are $95 \%$ percentile intervals. 


\section{Data for the Narrative Tax Changes}

In this part of the appendix, we describe the decomposition of the total tax liabilities changes of various legislative actions as recorded by Romer and Romer (2009) and after eliminating those implemented more than a quarter after their legislation as in Mertens and Ravn (2012) into various subcomponents: corporate income tax liabilities (CI), individual income liabilities (II), employment taxes (EM) and a residual category with other revenue changing provisions (OT). Whenever they provide sufficient information, we rely on the same sources as Romer and Romer (2009) for the decomposition. In many cases, additional sources had to be consulted for allocating the total changes to different categories. For a few legislative actions, summing the individual changes leads to slightly different totals than those reported by Romer and Romer (2009), but these differences are very small.

\section{Tax Changes}

\section{Revenue Act of 1948}

Total: 1948Q2:-\$5 billion (II)

The act reduced marginal tax rates on individual income for all taxpayers, with the percentage reduction in rates being largest for low-income taxpayers. It also increased the personal exemption and the standard deduction (Romer and Romer (2009), Carlson (1987)). Most of the decline is in personal income taxes, only a small fraction being due to reductions in estate and gift taxes (1948 Midyear Economic Report (p. 21)). We assign the entire amount in the individual income tax category.

\section{Internal Revenue Code of $\mathbf{1 9 5 4}$}

Total: 1954Q3: - $\$ 1.4$ billion (II: $-\$ 0.8$ billion, CI: $-\$ 0.6$ billion)

The 1954 Internal Revenue code was a complicated change to the tax law. The 1955 Economic Report describes the components of the bill: "A program of structural tax changes was enacted under the Internal Revenue Code of 1954. Many of these changes were designed to 
encourage economic growth; they include more liberal depreciation allowances, a tax credit to reduce double taxation of dividends, a lengthening from one to two years of the period over which net business losses may be carried back, and more liberal tax treatment of research and development expenditures of business. Other revisions, designed to correct inequities, include increased allowances for medical expenses and for certain dependents, a new allowance for child-care expenses, and more liberal rules governing the personal tax treatment of medical insurance and sick benefits received by employees. It is estimated that these structural revisions will reduce receipts in fiscal year 1955 by approximately 1.4 billion dollars" (1955 Economic Report p. 112). The 1954 Treasury Annual Report (p. 44) provides an estimate of the impact of the bill that is separated by component. The report states that the bill lowers taxes on individuals by $\$ 0.8$ billion and lowers taxes on corporations by $\$ 0.6$ billion (p. 44 ).

\section{Tax Rate Extension Act of 1958}

Total: 1958Q3: - $\$ 0.5$ billion (OT)

The Tax Rate Extension Act of 1958 was a tax decrease targeted at the transportation industry. The bill included cuts on excise taxes on the transportation of oil, coal, and other goods (Romer and Romer (2009)).

\section{Federal-Aid Highway Act of 1959}

Total: 1959Q4: \$0.6 billion (OT) .

The Federal-Aid Highway Act of 1959 was an excise tax increase that raised the tax on gasoline by 1 cent per gallon. (Romer and Romer (2009))

\section{Changes in Depreciation Guidelines and Revenue Act of 1962}

Total: 1962Q3 -\$1.35 billion (CI); 1962Q4: -\$0.9 billion (CI) 1963Q1: \$0.6 billion (OT)

The Changes in Depreciation Guidelines increased the rate at which firms could write-off plant and equipment, and therefore reduced corporate income tax liabilities. The Revenue Act 
of 1962's major component was the investment tax credit. These two tax changes were typically discussed as a pair, and are therefore presented by Romer and Romer (2009) jointly. As the major revenue impact of these tax changes was due to changes in depreciation allowances and the investment tax credit, we classify their revenue impact under the category of corporate income taxes. In addition there were other provisions, which we classify in the 'other' category, regarding the treatment of expense accounts, elimination of certain deductions and exemptions for mutual savings banks and savings and loan associations, inclusion of underwriting gains and losses in taxable income of mutual fire and casualty insurance companies and other minor provisions. Some provisions aimed at rasing tax compliance are not included (Romer and Romer (2009)). The tax changes were not all implemented at the same time, so we need to further distinguish between the changes in corporate income taxes according to their timing. The 1963 Treasury Annual Report, (p. XXI) states that the combined revenue effect of the depreciation changes and investment tax credit to be $\$ 2.25$ billion at an annual rate.

This figure is supported by the 1963 Economic Report (p. 18) and the 1962 Treasury Annual Report (p. 68-69). According to the 1962 Treasury Annual Report (p. 68-69), the investment tax credit amounted to a tax cut of $40 \%$ of $\$ 2.25$ billion, or $\$ 0.9$ billion. The remaining $60 \%$, or $\$ 1.35$ billion, are changes in depreciation allowances. The 1962 Treasury Annual Report (p. 68-69) puts the combined revenue impact of the other provisions (excluding compliance measures) at $\$ 0.6$ billion.

\section{Revenue Act of $\mathbf{1 9 6 4}$}

Total: 1964Q2: $-\$ 8.4$ billion (II: $-\$ 6.7$ billion; CI: $-\$ 1.7$ billion )

The Revenue act of 1964 reduced tax rates for both individuals and corporations in two stages. The 1965 Economic Report (p.67) reports the effect of the first round of cuts, made retroactive to January 1964 , as $\$ 8.4$ billion dollars at 1964 income levels, with $\$ 6.7$ billion due to the cut in individual income taxes and $\$ 1.7$ billion due to the cut in corporate income taxes.

\section{Excise Tax Reduction Act of $\mathbf{1 9 6 5}$}


Total: 1965Q3: - $\$ 1.75$ billion (OT)

The Excise Tax Reduction Act of 1965 reduced the excise tax on a number of consumer products, including appliances such as air conditioners, sporting goods, and automobiles (Carlson (1987), Romer and Romer (2009)).

\section{Tax Adjustment Act of 1966}

Total: 1966Q2: \$0.9 billion (OT)

The Tax Adjustment Act of 1966 reinstated the December 31, 1965 level of excise taxes on automobiles and telephone service (Romer and Romer (2009)). The act also introduced graduated withholding of individual income taxes and accelerated corporate income taxes, neither of which altered tax liabilities (Carlson (1987)).

\section{Public Law 90-26 (Restoration of the Investment Tax Credit)}

Total: 1967Q3: -\$1.6 billion (CI)

This bill reinstated the 7 percent investment tax credit, which had been temporarily suspended by Public Law 89-800, approximately six months sooner than originally called for . It also raised the ceiling and contained retroactivity provisions that had the effect of making the ITC apply to almost all investment that occurred during the period of suspension (Romer and Romer (2009)).

\section{Reform of Depreciation Rules}

Total: 1971Q1: $-\$ 2.8$ billion (CI)

The tax cut took the form of a revision in the depreciation guidelines for business investment. In particular, the reforms shortened the assumed life of the equipment and allowed more of the depreciation to be claimed in the first year (Romer and Romer (2009)). Several sources report an aggregate revenue effect for the 1971 depreciation reform of $\$ 2.7$ billion (1971 Economic 
Report; p. 6, 1972 Budget, p. 11, 72) for fiscal 1972. The 1972 Economic Report states that the reform reduced taxes on business income by $\$ 2.8$ billion (p. 33). The 1972 Budget also describes the full revenue effect as falling onto corporate income (p. 75).

\section{Revenue Act of $\mathbf{1 9 7 1}$}

Total: 1972Q1:-\$8 billion (II: -\$3.8 billion; CI: - $\$ 1.6$ billion; OT:-\$2.6 billion)

The four main components of the Revenue Act of 1971 are the reimposition of the investment tax credit ITC (referred to as the Job Development Credit), the repeal of the excise tax on cars and light trucks, changes to depreciation guidelines and a rise in personal exemption. Two sources provide disaggregated data on the revenue effects: the 1973 Budget and the Congressional Records. The fiscal year numbers from both sources are very similar. Romer and Romer (2009) rely on the Congressional records, as these also provide calendar year figures. Only the 1973 Budget, however, disentangles the individual and corporation income tax revenue effects of the investment tax credit and depreciation allowance changes. We use

the figures from the Congressional Records such that our implied aggregates are identical to Romer and Romer (2009). We split the revenue effects of the investment incentive measures by using the proportions implied by the numbers in the 1973 Budget.

The Job Development Credit was retroactive to 15 August 1971 and decreased tax revenues for fiscal 1972 by $\$ 0.4$ billion for individuals and by $\$ 2.1$ for corporations, according the 1973 Budget (p. 66). The Congressional record reports a total revenue impact of $-\$ 1.5$ billion for calendar 1971 and $-\$ 3.6$ billion for calendar 1972 due to the reimposition of the ITC (Congressional Record, 92nd Congress,1st Session, Vol. 117-Part 35, 12/9/71, p. 45857). We allocate $0.4 / 2.5 \times-1.5$ or $-\$ 0.2$ billion for 1971 and $0.4 / 2.5 \times-3.6$ or $-\$ 0.6$ billion for 1972 to individual income tax revenues. Similarly, we allocate $2.1 / 2.5 \times-1.5$ or $-\$ 1.3$ billion for 1971 and $2.1 / 2.5 \times-3.6$ or $-\$ 3.0$ billion for 1972 to corporate income tax revenues. A second component was the repeal of the excise tax on cars and light trucks, which was also retroactive to 15 , August 1971. The Congressional record reports a total revenue impact of $-\$ 0.9$ billion for calendar 1971 and $-\$ 2.6$ billion for calendar 1972 due to the repeal (Congressional Record, 
92nd Congress,1st Session, Vol. 117-Part 35, 12/9/71, p. 45857). The change in depreciation guidelines increased tax revenues for fiscal 1972 by $\$ 0.4$ billion for individuals and by \$2.0 for corporations, according the 1973 Budget (p. 66). The Congressional record reports a total revenue impact of $\$ 2.1$ billion for calendar 1971 and $\$ 1.7$ billion for calendar 1972 (Congressional Record, 92nd Congress, 1st Session, Vol. 117-Part 35, 12/9/71, p. 45857). We allocate $0.4 / 2.4 \times 2.1$ or $\$ 0.4$ billion for 1971 and $0.4 / 2.4 \times 1.7$ or $\$ 0.3$ billion for 1972 to individual income tax revenues. Similarly, we allocate $2.0 / 2.4 \times 2.1$ or $\$ 1.7$ billion for 1971 and $2.0 / 2.4 \times 1.7$ or $\$ 1.4$ billion for 1972 to corporate income tax revenues. The remaining components primarily affected individual income tax revenues. They constituted of increases in personal exemption, in part retroactive. The Congressional Record reports a total revenue impact of $-\$ 1.4$ billion for calendar 1971 and $-\$ 3.5$ billion for calendar 1972 (Congressional Record, 92nd Congress,1st Session, Vol. 117-Part 35, 12/9/71, p. 45857). The total numbers reported ignore the retroactive components and are obtained by netting the retroactive numbers.

\section{Tax Reform Act of $\mathbf{1 9 7 6}$}

Total: 1976Q4: \$2.4 billion (II: \$1.65 billion; CI \$0.75 billion); 1977Q1:-\$0.8 billion (OT)

The Tax Reform Act of 1976 made a number of changes to the tax law, such as changes in gift and estate taxes, an increase in the minimum tax, and various measures to close loopholes. Romer and Romer (2009) rely on the 1977 Economic Report arriving at an annualized $\$ 2.4$ billion total increase in revenues for 1976. The 1978 Budget (p. 60) provides disaggregated numbers for the effects of the bill for fiscal 1977 that are very much consistent with the aggregate numbers for 1977 in the Economic Report. The 1978 Budget breakdown of the revenue effects of the reform includes tax shelter provisions and tax simplification measures canceling each other out with an impact of $\$ 0.4$ billion and $-\$ 0.4$ billion for fiscal 1977 , respectively (p. 60). The net effect is zero, therefore, we include only the figures provided for the change in the minimum tax for individuals ( $\$ 1.1$ billion in fiscal 1977), the amendments affecting Domestic International Sales Corporations (\$0.5 billion in fiscal 1977). We use the 
same proportions to deduce the effect for 1976 , i.e. $(1.1 / 1.6) \times 2.4$ or $\$ 1.65$ billion increase in individual revenues and $(0.5 / 1.6) \times 2.4$ or $\$ 0.75$ billion increase in corporate tax revenues. The reforms to gift and estate taxes ( $\$ 0.7$ billion, according to 1978 Budget; $-\$ 0.8$ based on 1977 Economic Report) took place with a delay in January 1977 and are classified as "other".

\section{Tax Reduction and Simplification Act of 1977}

Total: 1977Q3: - $\$ 7$ billion (II: $-\$ 5.4$ billion; CI: $-\$ 1.6$ billion)

The main component of the Tax Reduction and Simplification Act of 1977 was a permanent increase in the standard deduction. Among the the other changes the most significant was the introduction of a temporary job credit for businesses. The 1978 Economic Report (p.52) provides revenue estimates for individual and corporate income tax revenue effects in fiscal 1977 of $-\$ 3.3$ billion and $-\$ 1.6$ billion, respectively. We subtract another $\$ 2.1$ billion in individual income tax revenues to account for the withholding effect on individual taxpayers (1979 Budget (p. 50), Romer and Romer (2009)).

\section{Revenue Act of 1978}

Total: 1979Q1:-\$21.3 billion (II: -\$14.8 billion; CI: $-\$ 6.5$ billion)

The Revenue Act of 1978 lowered corporate and personal tax rates. The 1979 Economic Report (p.93) puts the total effect of the bill at $-\$ 18.9$ billion, consisting of a $\$ 14.1$ billion cut in personal taxes, a $\$ 6.5$ billion cut in business taxes, a $\$ 0.7$ increase in outlays for the earned income tax credit, but also a $\$ 2.5$ billion increase in revenues due to the expiration of job credits to businesses. The 1979 CBO estimates for the individual components of this bill provided in the $1998 \mathrm{CBO}$ document on the projection of tax revenues are : individual income taxes $-\$ 7.9$ billion, corporate income taxes $-\$ 2.0$ billion, capital gains and minimum tax $-\$ 0.3$ billion, while extending or making permanent certain provisions would lead to a revenue effect of $-\$ 8.9$ billion (CBO, Projecting Federal Tax Revenues and the Effect of Changes in Tax Law p. 12). This last component of extending or making permanent certain provisions is 
vague, but this is the only detail the $\mathrm{CBO}$ provides. The $\mathrm{CBO}$ estimates for the Revenue Act of 1978 put the aggregate effect of the bill at $-\$ 19.3$ billion for 1979 , which is very close to the aggregate impact of $-\$ 18.9$ billion reported in the 1979 Economic Report. Another CBO document pertaining to 1978 the tax cut proposals contains a breakdown between individual and corporate tax revenue effects that is very close to the one implied by the 1979 Economic Report (CBO, Statement of Alice M. Rivlin, Director, Congressional Budget Office, Before the Committee of the Budget, United States Senate, July 26, 1978, p 12). We therefore adhere to the numbers in the 1979 Economic Report and classify \$0.7 in cuts due to increase in the earned income tax credit as a further decrease in individual tax revenues, obtaining a total decrease of $\$ 14.8$ billion. We choose not to incorporate the $\$ 2.5$ billion due the expiration of job credits. These were classified in the 1977 Tax Reduction and Classification Act as temporary with and expiration date of end 1978 and therefore do not constitute a separate action. As

a result our aggregate estimate of the revenue impact is a cut of $\$ 21.3$, as opposed to $\$ 18.9$ reported in Romer and Romer (2009).

\section{Crude Oil Windfall Profit Tax Act of 1980}

Total: 1980Q2: \$8.2 billion (OT)

The Crude Oil Windfall Profit Tax Act of 1980 was in reality an excise tax on domestic crude oil imposed at the wellhead (Romer and Romer (2009)).

\section{Economic Recovery Tax Act of $\mathbf{1 9 8 1}$}

Total: 1981Q3:-\$8.9 billion (II: - \$4 billion; CI -\$4.8 billion; OT; $-\$ 0.1$ billion)

The Economic Recovery Tax Act of 1981 consisted of a permanent, across-the-board reduction in marginal tax rates in several stages. New depreciation guidelines and a reduction in corporate tax rates reduced business taxes as well (Romer and Romer (2009)). The 1983 Budget (p.4-9 and 4.10) provide the decomposition of the decline in tax revenues of the first stage: individual income taxes are reduced by $\$ 4.0$ billion, corporate income taxes by $\$ 4.8$ billion, 
while excise taxes, classified as 'other', were reduced by $\$ 0.1$ billion.

\section{Deficit Reduction Act of $\mathbf{1 9 8 4}$}

Total:1984Q3 \$9.3 billion (II: \$5.6 billion, CI: \$3.3 billion, OT: $\$ 0.4$ billion)

The Deficit Reduction Act of 1984 postponed or repealed several tax reductions scheduled to take effect after 1984, which included the net interest exclusion, the increased ability to transfer tax benefits through leasing arrangements, the increased eligibility for expensed property, and lower rates for estate and gift taxes and telephone excise taxes, among other changes (CBO, Projecting Federal Tax Revenues and the Effect of Changes in Tax Law p. 16). The legislation included a large number of minor provisions that raised revenues from corporate and individual taxpayers. Romer and Romer (2009) rely on the CBO estimates for calculating the revenue effects of this bill. As calendar year numbers are not available, the revenue effects adopted are for fiscal year 1985. Backing out the effect of the postponements of scheduled tax cuts from the CBO data, the aggregate revenue estimate in Romer and Romer (2009) for fiscal 1985 is $\$ 8$ billion (CBO, Projecting Federal Tax Revenues and the Effect of Changes in Tax Law p.22). However, the CBO breakdown of the Deficit Reduction Act of 1984 (excluding the postponements) is not very informative for our purposes: limits on tax-exempt financing, \$1 billion, changes in accounting rules, $\$ 1$ billion, modification of income averaging, $\$ 2$ billion, and other, $\$ 4$ billion (CBO, Projecting Federal Tax Revenues and the Effect of Changes in Tax Law p. 22). Therefore, we adopt the disaggregated numbers in the 1986 Budget, p. 4-8, which are also identical to those reported in the 1987 Budget (p. 4-6). Although this means our numbers include some revenue effects that are due the postponements of scheduled tax cuts, the implied aggregate revenue effect of the bill of $\$ 9.3$ billion for fiscal 1985 is reasonably close to the $\$ 8$ billion in Romer and Romer (2009).

\section{Tax Reform Act of $\mathbf{1 9 8 6}$}

Total: 1986 Q4: \$22.7 billion (CI); 1987Q1 -\$7.2 billion (II) 
The Tax Reform Act of 1986 significantly reduced individual income tax liabilities, broadened the individual tax base, and increased corporate liabilities, and was the only complete revision of the Internal Revenue Code since 1954 (CBO, Projecting Federal Tax Revenues and the Effect of Changes in Tax Law p. 21). The first stage of the tax reform was the repeal of the investment tax credit. Romer and Romer (2009) attribute a revenue effect of this particular repeal of $\$ 22.7$ billion at an annual rate dated to $1986 \mathrm{Q} 4$. We adopt their number and classify it as an increase in corporate income tax revenues. The tax change in 1987Q1 is harder to attribute because no adequate source is available. The CBO, Projecting Federal Tax Revenues and the Effect of Changes in Tax Law p. 25, however, strongly suggests that the bulk of the tax cuts fell onto individual income taxes. Consequently, we assign the entire $\$ 7.2$ billion cut into that category.

\section{Omnibus Budget Reconciliation Act of $\mathbf{1 9 8 7}$}

Total: 1988Q1: $\$ 10.8$ billion (II: $\$ 0.1$ billion; CI: $\$ 7.5$ billion; OT: $\$ 2.5$ billion; EM: \$0.7 billion)

The Omnibus Budget Reconciliation Act of 1987 increased corporate income taxes, repealed the installment-sales method of accounting and the use of a vacation-pay reserve, and restricted both the use of the completed-contract method of accounting and the deductions for dividends received from affiliated companies (CBO, Projecting Federal Tax Revenues and the Effect of Changes in Tax Law p. 24). The Conference Report (100th Congress, 1st Session, House of Representatives Report No. 100-495, 12/21/87, pp. 1024-1025) gives a detailed breakdown of the components of the act in order to estimate their revenue effects, and is also the source of the revenue estimates of Romer and Romer (2009). Romer and Romer take the revenue estimate of the act for fiscal 1989 provided by the document of $\$ 14.4$ billion, but subtract $\$ 3.6$ billion of provisions that postponed scheduled tax cuts or accelerated collections, yielding an aggregate revenue estimate of $\$ 10.8$ billion. We use the disaggregated figures in the Conference Report, eliminating items II-C1, III, V-1, VII-2. 


\section{Omnibus Budget Reconciliation Act of 1990}

Total: 1991Q1: $\$ 33$ billion (II: $\$ 4.0$ billion; CI: $\$ 1.0$ billion; OT: $\$ 18$ billion; EM: $\$ 10$ billion)

The Omnibus Budget Reconciliation Act of 1990 increased taxes in a number of ways. There were rises in the tax rates for very high earners, and reductions for moderately high earners, as well as excise tax increases on gasoline and other fuels. The act also increased payroll taxes by nearly tripling the amount of earnings subject to the Medicare tax (Romer and Romer (2009)). Romer and Romer (2009) rely on a figure of $\$ 35.2$ billion for the total revenue impact provided by the 1992 Budget (Part three, p.7) in calculating their estimate for the impact of the bill in 1991Q1, but we will rely on the CBO data as this provides a very close estimate of $\$ 33$ billion and allows us to disentangle the revenue effects by component (CBO, Projecting Federal Tax Revenues and the Effect of Changes in Tax Law p. 31).

\section{Omnibus Budget Reconciliation Act of 1993}

Total: 1993Q3: \$22.8 billion (II); 1993Q4: \$5.3 billion (OT)

The Omnibus Reconciliation Act of 1993 increased income taxes, mostly for higher earners, and contained various other revenue-increasing provisions such as excise tax changes, changes in Federal payroll taxes, changes in corporate income taxes among others. A Joint Committee on Taxation document (Estimated Budget Effects of the Revenue Provisions of H.R. 2264 (The Omnibus Reconciliation Act of 1993) as Agreed to by the Conferees, JCX11-93, 8/4/93) provides a by-component breakdown of the revenue implications, including details on the retroactive components. The revenue effects for the first stage of the tax reform are almost entirely due to the increase in tax rates paid by high-income individuals, which was retroactive until 1/1/93. We therefore classify the entire revenue effect in 1993Q3 as an increase in individual income taxes. Some provisions went into effect in 1993Q4, most notably an increase in gasoline tax, which according to the Joint Committee on Taxation document accounts for virtually the entire revenue increase. 


\section{Jobs and Growth Tax Relief Reconciliation Act of 2003}

Total: 2003 Q3: \$126.4 billion (II:-\$ 94.6 billion; CI: -\$31.2 billion )

The Jobs and Growth Tax Relief Reconciliation Act of 2003 affected both Federal individual and corporate income taxes. Romer and Romer (2009) explain the revenue effects of the bill by component, which allows us to borrow their numbers and calculations for finding the revenue effects of the changes in individual and corporate income tax rates. The bill lowered Federal income taxes by a reduction in marginal tax rates, an expansion of the 10 percent tax bracket, reductions in rates on married couples, an increase in child credit, as well as lower taxes on dividends and capital gains. The corporate income tax cut took the form of an extension of the bonus depreciation features of the 2002 tax cut, which allowed firms to claim bonus depreciation on investments made after September 11 (see Romer and Romer (2009)). 


\section{References}

Budget of the United States Government, U.S. Office of Management and Budget. Various years.

Carlson, Keith M., 1987, "Federal Fiscal Policy Since the Employment Act of 1946 ", Federal Reserve Bank of St Louis Review, December

Congressional Budget Office, Various reports and documents

Congressional Record, U.S. Congress. Various issues.

Economic Report of the President, US Office of the President, various years.

Fisher, Jonas D.M. and Ryan Peters, 2010, "Using Stock Returns to Identify Government Spending Shocks", Economic Journal 120(544), pp. 414-436.

Francis, Neville and Valerie A. Ramey, 2009, "Measures of per Capita Hours and Their Implications for the Technology-Hours Debate", Journal of Money Credit and Banking 41(6), pp. 10711097.

House of Representatives Reports, U.S. Congress. Various numbers

Leeper, Eric M., Todd B. Walker and Shu-Chun Susan Yang, 2011, "Foresight and Information Flows", manuscript, Indiana University Bloomington.

Mertens, Karel and Morten O. Ravn, 2012, "Empirical Evidence on the Aggregate Effects of Anticipated and Unanticipated U.S. Tax Policy Shocks", American Economic Journal: Economic Policy, 4(2), pp.145-181.

Ramey, Valerie A., 2011, "Identifying Government Spending Shocks: It's All in the Timing", Quarterly Journal of Economics 126(1), pp. 10-50.

Romer, Christina D., and David H. Romer, 2009, "A Narrative Analysis of Postwar Tax Changes" , University of California, Berkeley, manuscript.

Annual Report of the Secretary of the Treasury on the State of the Finances, U.S. Department of the Treasury. Various years. 